
treatments induce resistance to Tuta absoluta and Tetranychus urticae on tomato plants. Horticultura Brasileira 38: 288-294. http://dx.doi.org/10.1590/ S0102-053620200308

\title{
Salicylic acid treatments induce resistance to Tuta absoluta and Tetranychus urticae on tomato plants
}

\author{
Paulo S Pulga ${ }^{1} \mathbb{D}$; Juliane M Henschel ${ }^{2} \mathbb{D}$; Juliano Tadeu V de Resende ${ }^{3} \mathbb{D}$; André R Zeist ${ }^{4} \mathbb{D}$; Aline Fabiana \\ P Moreira ${ }^{3} \mathbb{D}$; André Gabriel ${ }^{1} \mathbb{D}$; Mayara B Silva ${ }^{5} \mathbb{D}$; Leandro Simões A Gonçalves ${ }^{3} \mathbb{D}$
}

${ }^{1}$ Universidade Estadual do Centro-Oeste (UNICENTRO), Guarapuava-PR, Brasil; psplinho@gmail.com; andreagrounicentro@gmail.com; ${ }^{2}$ Universidade Federal de Viçosa (UFV), Viçosa-MG, Brasil; julianemhenschel@gmail.com; ${ }^{3}$ Universidade Estadual de Londrina (UEL), Londrina-PR, Brasil; jvresende@uel.br (author for correspondence); fabianapaladini@gmail.com; leandrosag@uel.br. ${ }^{4}$ Universidade do Oeste Paulista (UNOESTE), Presidente Prudente-SP, Brasil; andre.zeist@bol.com.br. ${ }^{5}$ Universidade Estadual de Maringá (UEM), MaringáPR, Brasil; mayarabarbosa2012@gmail.com

\begin{abstract}
This study was performed to evaluate the effect of exogenous application of salicylic acid as a resistance inducer to two-spotted spider mite and tomato pinworm on tomato genotypes. Bioassays were carried out in three commercial genotypes ('Redenção', 'Giuliana', and 'Alambra') and one wild genotype (Solanum habrochaites var. hirsutum, accession PI-127826). Average distance travelled by the two-spotted spider mite and number of eggs deposited over the leaflets of the genotypes were investigated. Concerning pinworm bioassay, number of eggs, leafminers on leaflet surface and percentage of leaf area consumed by leafminers were evaluated using a scanner. Furthermore, severity of attack to plants was evaluated by score scale for damages, types of lesions and attacked leaflets. Salicylic acid application induced resistance in the commercial genotypes against both pests, reducing the two-spotted spider mite and pinworm oviposition. The spider mites travelled shorter distance on leaflets of genotypes treated with salicylic acid at intermediate concentrations, indicating a positive effect of substance as inducing resistance. Attack severity by pinworm was also reduced when intermediate doses of salicylic acid were applied. Also, higher resistance was observed on accession PI-127826 as compared to other genotypes. The obtained results indicate that the resistance of PI-127826 was due to constitutive defense, whereas on commercial genotypes defense was dependent on responses mediated by salicylic acid. Hence, salicylic acid treatment, as resistance inducer, seems to be efficient against two-spotted spider mite and pinworm, being a promising tool within an integrated pest management on tomato plants.
\end{abstract}

Keywords: Solanum habrochaites var. hirsutum, Tuta absoluta, Tetranychus urticae, methyl salicylate, induced resistance.

\section{RESUMO}

Ácido salicílico induz resistência à Tuta absoluta e Tetranychus urticae em tomateiro

Objetivou-se avaliar os efeitos da aplicação exógena de ácido salicílico como indutor de resistência ao ácaro-rajado e à traça em genótipos de tomateiro. Para isso, realizaram-se bioensaios com três genótipos comerciais ('Redenção', 'Giuliana' e 'Alambra') e um silvestre (Solanum habrochaites var. hirsutum acesso PI-127826). Determinou-se a distância média percorrida pelo ácaro-rajado e o número de ovos depositados sobre os folíolos dos genótipos. Com relação ao bioensaio da traça-do-tomateiro, foram avaliados o número de ovos e lagartas na superfície do folíolo e a porcentagem de área foliar consumida pelas lagartas por meio de digitalização dos folíolos. Além disso, avaliou-se a severidade do ataque na planta utilizando uma escala de notas referente a danos, tipos de lesões e folíolos atacados. A aplicação de ácido salicílico induziu resistência nos genótipos comerciais para ambas as pragas, diminuindo a oviposição do ácaro e da traça do tomateiro. Os ácaros percorreram menor distância nos folíolos dos genótipos que receberam tratamento com ácido salicílico nas concentrações intermediarias, indicando efeito benéfico da substância na indução de resistência. A severidade do ataque da traça do tomateiro, também foi coibida quando aplicadas doses intermediárias de ácido salicílico. Entretanto, observou-se resistência superior do acesso PI-127826 em relação aos demais genótipos. Isso indica que a resistência de PI-127826 se deve à defesa constitutiva, enquanto que nos genótipos comerciais as defesas são dependentes, em parte, de respostas de indução mediadas pelo ácido salicílico. Dessa forma, pode se inferir que o ácido salicílico é eficiente como indutor de resistência ao ácaro rajado e à traça-dotomateiro, sendo bastante promissor dentro de um manejo integrado de pragas em cultivos comerciais de tomateiro.

Palavras-chave: Solanum habrochaites var. hirsutum, Tuta absoluta, Tetranycus urticae, metil salicilato, indução de resistência.

\section{Received on September 26, 2019; accepted on July 1, 2020}

A mong the different biotic stresses to which tomato plants are exposed during cultivation, pest arthropods are the most damaging (Silva et al., 2019).
In particular, pinworm (Tuta absoluta), a chewing herbivore that causes large damages due to galleries created on the leaf mesophyll by its leafminers on the leaf mesophyll, which also affects petioles, stems, and fruits, causing high production losses (Dias et al., 2019). Another arthropod pest that causes 
large losses in tomato plants is the two-spotted spider mite [Tetranychus urticae, (Acari: Tetranychidae)], a generalist sucking pest that feeds by punching leaf mesophyll cells with its stylets (Zanin et al., 2018). The large proportion of damages caused by those species is related to the presence of overpopulations in cultivated areas.

Generally, the intensive use of pesticides can lead to increased costs and environmental damage, as well as potential harm towards consumer and producer health (Youssef et al., 2019). In this scenario, the use of pestresistant tomato genotypes appears as an adequate alternative to agrochemicals (Zanin et al., 2018). In particular, control of arthropod-pests on crop plants is performed mainly with agrochemical applications, which have resulted in problems such as high production costs, the development of genetic resistance and residual damages to the environment (Ilias et al., 2017). In this sense, the elucidation of defense mechanisms of tomato plants can be a way to assist the pest control and, thus, to reduce the use of pesticide applications.

Plants respond to stresses by triggering a series of events, including the transcription of genes involved in the biosynthesis of plant hormones involved in defense responses (Bostock et al., 2014). Among these plant hormones, the salicylates (SA), jasmonates (JA) and ethylene (Et) are known to modulate plant defense responses (Brodersen et al., 2006; Aljbory \& Chen, 2017).

The signaling pathway induction of those plant hormones is triggered according to the type of feeding habit of the arthropods. The SA pathways are associated mainly with hypersensitivity responses and acquired systemic resistance (Yan \& Dong, 2014), while herbivory defenses have been related to JA pathways (Howe \& Jander, 2008; Ojha \& Chatterjee, 2012). However, studies have shown that SA may also be associated with defense against herbivory (Schweiger et al., 2014; Aljbory \& Chen, 2017; Favaro et al., 2019).

Therefore, in the present study we aimed to evaluate the effect of exogenous application of salicylic acid as a resistance inducer against the twospotted spider mite and pinworm on tomato genotypes.

\section{MATERIAL AND METHODS}

Pests bioassays were conducted at the Universidade Estadual do CentroOeste do Paraná (UNICENTRO) from October 2015 to May 2016. The tomato plants were grown in pots and kept in a greenhouse with controlled environment. Different salicylic acid concentrations $(25,50,75$, and 100 $\mathrm{mg} \mathrm{L}^{-1}$ ) were applied to evaluate the influence on tomato resistance against attack of spider mite (T. urticae, sucking pest) and pinworm (T. absoluta, chewing pest).

\section{Plant material and treatment} application

For bioassay with two-spotted spider mite (T. urticae), three commercial tomato genotypes were used, including Solanum lycopersicum $\mathrm{F}_{1}$ hybrid Alambra (shelf life), $\mathrm{F}_{1}$ hybrid Giuliana (salad) and Redenção cultivar (for industrial processing), in addition to a wild species resistant to pests $S$. habrochaites var. hirsutum accession PI127826 (Maluf et al., 2007). Bioassay with pinworm (T. absoluta) was carried out with 'Alambra' and 'Redenção' and accession PI-127826.

Genotypes were seeded on polypropylene boxes containing biostabilized pine bark-based commercial substrates. About 30 days after sowing, seedlings were transplanted to polypropylene pots $\left(7 \mathrm{dm}^{3}\right)$ filled with subsurface soil corrected according to chemical analysis and commercial substrate (1:1). Each pot was considered as an experimental plot.

Plants were treated either with four concentrations of salicylic acid $\left(25,50,75\right.$, and $\left.100 \mathrm{mg} \mathrm{L}^{-1}\right)$ or with water as check control treatment. Treatments were applied weekly after plants presented four fully expanded leaflets. For the two-spotted spider mite test, treatments were applied eight times (up to 50 days after transplant). For pinworm, two applications were carried out, at 15 and 30 days after infestation. Treatments were applied with a backpack sprayer adapted with a constant pressure valve (Jacto ${ }^{\circledR}$ ) with $2 \mathrm{kgf} \mathrm{cm}^{-2}$ pressure, cone nozzle $\mathrm{X} 2$ (2/110), $1.05 \mathrm{~m} \mathrm{~s}^{-1}$ speed and plastic curtains to prevent drift in the neighboring plots. Randomized blocks design in a factorial arrangement with four replicates was used.

\section{Bioassay - Tetranychus urticae}

Spider mites used in the bioassay were obtained from a stock rearing maintained in common bean plants (Phaseolus vulgaris) on the Laboratory of Agricultural Entomology (UNICENTRO). Spider mite resistance test was performed at the pre-flowering stage (50 days after transplanting) following the methodology proposed by Weston \& Snyder (1990). Young leaflets, fully expanded and with similar sizes, were taken from the upper third of plants and maintained in a controlled environment room located at the Laboratory of Agricultural Entomology $\left(67.0 \pm 3 \%\right.$ relative humidity and $15 \pm 2^{\circ} \mathrm{C}$ temperature).

After that, each leaflet was fixed with a $9 \mathrm{~mm}$ diameter brass thumbtack in its center on a white sulphite paper sheet, A4 size (212 x $297 \mathrm{~mm})$, placed on a polystyrene board. The adaxial surface of the leaves was kept facing upwards. Then, ten female mites were transferred to the thumbtack center using a brush. Subsequently, the distance travelled (WD) by mites ( $\mathrm{mm}$ ) on the surface of each leaflet from the center of thumbtack was determined with a ruler 20, 40 and 60 minutes after pest released. When mites remained on thumbtack, distance was considered zero. When they left leaflet surface towards the surface of the paper sheet, the travelled distance was considered that from the center of thumbtack to the end of the leaflet. The distance covered by each mite at 20 , 40 and 60 minutes was measured for each time to obtain the final average of the distances for each treatment (Zanin et al., 2018). Experimental design was completely randomized with five replications. Treatments were four genotypes [Alambra, Giuliana, Redenção and S. habrochaites var. hirsutum (PI-127826)] and four concentrations of salicylic acid $(25$, 50,75 and $100 \mathrm{mg} \mathrm{L}^{-1}$ ) besides witness 
(application with water), totalizing 100 leaflets.

\section{Bioassay - Tuta absoluta}

Pinworm bioassay was carried out in a greenhouse with a controlled environment (Dias et al., 2019). The temperature was set to $29 \pm 4^{\circ} \mathrm{C}$ during the day and to $22 \pm 4^{\circ} \mathrm{C}$ during the night, with 12 hours daylength and $78 \pm 3 \%$ relative humidity. Plants were infested with pinworm 50 days after transplanting in the pre-flowering stage. The experimental design was completely randomized, with four replications. Treatments were four genotypes [Alambra, Giuliana, Redenção and $S$. habrochaites var. hirsutum (PI-127826)] and four concentrations of salicylic acid $\left(25,50,75\right.$ and $\left.100 \mathrm{mg} \mathrm{L}^{-1}\right)$ in addition to the witness treatment (application with water). Each replicate consisted of 15 plants totalizing 60 plants for the entire experiment. Pinworms were created on susceptible tomato plants (cultivar Santa Cruz). Plants were grown in pots placed inside voile cages (100 x 100 $\mathrm{cm}$ ) of PVC structure that were kept inside a greenhouse under controlled temperature $\left(27 \pm 3^{\circ} \mathrm{C}\right)$. To standardize the infestation, deposited eggs were transferred every three days to a new set of susceptible 'Santa Clara' plants (not infested) that were also placed in voile cages. After 18 days, two pots of the new set of 'Santa Cruz' plants, infested with eggs and leafminers, were randomly placed inside each block.

Number of eggs (NE) and leafminers (NL) of pinworm was determined in three leaflets on the upper third of plants at $15,25,35,45$, and 55 days after infestation. The eggs were counted with a stereoscopic microscope on the abaxial and adaxial surface of the leaflet in an area of $10 \mathrm{~cm}^{2}$. Leafminers were counted within an area of $10 \mathrm{~cm}^{2}$ of the sampled leaflet surface. Number of eggs and leafminers correspond to the average of the three sampled leaflets obtained during the five evaluations $(15,25,35$, 45 , and 55 days after infestation).

Assessments of damage severity were carried out 20 and 60 days after infestation, according to a score scale proposed by Labori et al. (1999) described as follows: A) Intensity of damage to plants (IDP) $[0=$ no damage;
$1=$ small injuries $(0.1$ to $5 \%$ damage $)$; $2=$ small, non-coalescent lesions (5.1 to $20 \%$ damage); $3=$ medium to large injuries (20.1 to $50 \%$ damage); $4=$ large and coalescent lesions (50.1 to $80 \%$ of damage); and $5=$ plants completely destroyed (over 80\% damage)]. B) Types of lesions in the leaflets (TLL) $(0=$ no lesions; $1=$ few and minor injuries; $2=$ small and medium lesions; $3=$ medium-sized lesions, without coalescence; 4= large and coalescent lesions, deformed leaflets; and 5= leaflet completely destroyed). C) Percentage of attacked leaflets (PAL) $(0=$ without attacked leaflets; $1=0.1$ to $5 \%$ attacked leaflets; $2=5.1$ to $20 \%$ attacked leaflets; $3=20.1$ to $50 \%$ attacked leaflets; $4=50.1$ to $80 \%$ attacked leaflets; and $5=$ more than $80 \%$ attacked leaflets).

The intensity of damage to plants (IDP), types of lesions in the leaflets (TLL) and percentage of attacked leaflets (PAL) were determined by 5 previously trained evaluators. Extreme score values were discarded from the final weighting average.

To analyze the percentage of consumed leaf area, three whole leaves were harvested from each third of the plant (upper, middle and lower), from which, the six most distal leaflets were evaluated. Leaflets were scanned using an HP j4550 multifunction printer connected to a microcomputer. The images (300 dpi resolution) were analyzed using the Quant 1.0.1 software and the percentage of consumed leaf area by the leafminers was assigned according to the score of the damage scale.

\section{Statistical analysis}

The results were submitted to the normality (Shapiro-Wilk) and homogeneity tests (KolmogorovSmirnov). The analysis of variance (ANOVA) was performed when the assumptions were met. When statistical differences were found, the Tukey's test $(\mathrm{p} \leq 0.05)$ and polynomial regression analyses were performed using the software SISVAR (Ferreira, 2011) to estimate the adjustments of equations related to salicylic acid concentrations. Equations were derived for determining maximum and minimum points whenever necessary.

\section{RESULTS AND DISCUSSION}

Analysis of variance indicated significant interaction between variation factors (concentrations of salicylic acid and genotypes) for the travelled distance (WD) by mites on leaflet surface at 40 minutes after female release. On the other hand, the variation factors had significant effect on the travelled distance at 20 and 60 minutes only when taken individually. Concerning the leafminer's bioassay, the analysis of variance showed that the variation factors individually influenced the number of eggs (NE), number of leafminers (NL) and types of leaflet lesions (TLL). However, there was significant interaction between the variation factors on plant damage intensity (PDI), percentage of attacked leaflets (PAL) and percentage of consumed leaf area (PCL) by the leafminers.

Average travelled distances by spider mites on leaflets were plotted as a function of different concentrations of salicylic acid, presenting adjustment to the quadratic model. Reductions in spider mite travelled distance were observed for all concentrations tested, regardless the genotype (Figure 1). At 20 minutes, the quadratic model estimated the shortest travelled distance to occur at the SA concentration of $115.5 \mathrm{mg}$ $\mathrm{L}^{-1}$, with an average travelled distance of $14.41 \mathrm{~mm}$. In addition, the model indicated that the shortest average travelled distance by spider mites at 40 minutes $(13.34 \mathrm{~mm})$ and 60 minutes $(17.08 \mathrm{~mm})$ was expected to occur with SA concentrations of $97.25 \mathrm{mg} \mathrm{L}^{-1}$ and $109 \mathrm{mg} \mathrm{L}^{-1}$, respectively (Figure 1).

Regression analysis showed that the results of pinworm bioassay had quadratic adjustment when plotted as a function of salicylic acid concentrations, except for the number of leafminers (NL). Significant reductions were observed on the number of eggs of $T$. absoluta (2.5 eggs) at $51.0 \mathrm{mg} \mathrm{L}^{-1}$ of $\mathrm{SA}$ and on leaflet lesions at $43.5 \mathrm{mg} \mathrm{L}^{-1}$ of SA, according to the estimated model (Figure 2). 
The results obtained herein showed that SA application was effective in defense induction of tomato genotypes against herbivory, corroborating with Schweiger et al. (2014) who found a significant effect of both SA and JA application on defense induction against herbivory of sucking and chewing insects in Plantago lanceolata. Previously, most studies indicate that defense against herbivory is associated with jasmonate (JA) (Howe \& Jander,
2008) and that salicylate (SA) is mainly involved in defense against biotrophic pathogens (Ojha \& Chatterjee, 2012).

It's important to mention that, defense induction responses triggered by different classes of herbivores are conflicting. Aljbory \& Chen (2017) suggested that $\mathrm{SA}$ is associated with defense against sucking and puncturing insects, such as mites, and that protection against chewing insects, such as pinworm, is associated with

Table 1. Average travelled distance (WD) by spider mite (Tetranychus urticae) at 20, 40 and 60 minutes after exposure and number of eggs (NE), number of leafminers (NL), and types of leaflet lesions (TLL) caused by pinworm (Tuta absoluta) in tomato genotypes treated with salicylic acid. Guarapuava, UNICENTRO, 2016.

\begin{tabular}{|c|c|c|c|c|c|c|}
\hline \multirow{2}{*}{ Genotype } & \multicolumn{3}{|c|}{ WD (mm) } & \multirow{2}{*}{$\begin{array}{c}\mathrm{NE} \\
\left(4 \mathrm{~cm}^{2}\right)\end{array}$} & \multirow{2}{*}{$\begin{array}{c}\mathrm{NL} \\
\left(10 \mathrm{~cm}^{2}\right)\end{array}$} & \multirow{2}{*}{$\begin{array}{l}\text { TLL** } \\
\text { (grades) }\end{array}$} \\
\hline & $20 \mathrm{~min}$ & $40 \mathrm{~min}$ & $60 \mathrm{~min}$ & & & \\
\hline Alambra & $30.16^{*} \mathrm{a}$ & $31.02 \mathrm{a}$ & $33.18 \mathrm{~A}$ & $0.47 \mathrm{~A}$ & $2.97 \mathrm{a}$ & $1.99 \mathrm{a}$ \\
\hline Giuliana & $30.52 \mathrm{a}$ & $32.47 \mathrm{a}$ & $34.20 \mathrm{~A}$ & - & - & - \\
\hline Redenção & $27.06 \mathrm{a}$ & $27.49 \mathrm{~b}$ & $27.72 \mathrm{~B}$ & $0.39 \mathrm{~A}$ & $3.24 \mathrm{a}$ & $1.92 \mathrm{a}$ \\
\hline PI-27826 & $0.43 \mathrm{~b}$ & $0.56 \mathrm{c}$ & $0.62 \mathrm{C}$ & $0.26 \mathrm{~B}$ & $1.39 \mathrm{~b}$ & $1.27 \mathrm{~b}$ \\
\hline CV\% & 10.38 & 9.47 & 7.58 & 29.58 & 33.2 & 7.89 \\
\hline
\end{tabular}

*Means followed by equal letters belong to the same group by the Tukey's test at $5 \%$ probability; (-) Not evaluated; **Measured using a score scale ranging from 1 to 5 according to the type of lesion in the leaflet (-1 corresponds to absence of lesion and 5 corresponds to leaflets totally destroyed).

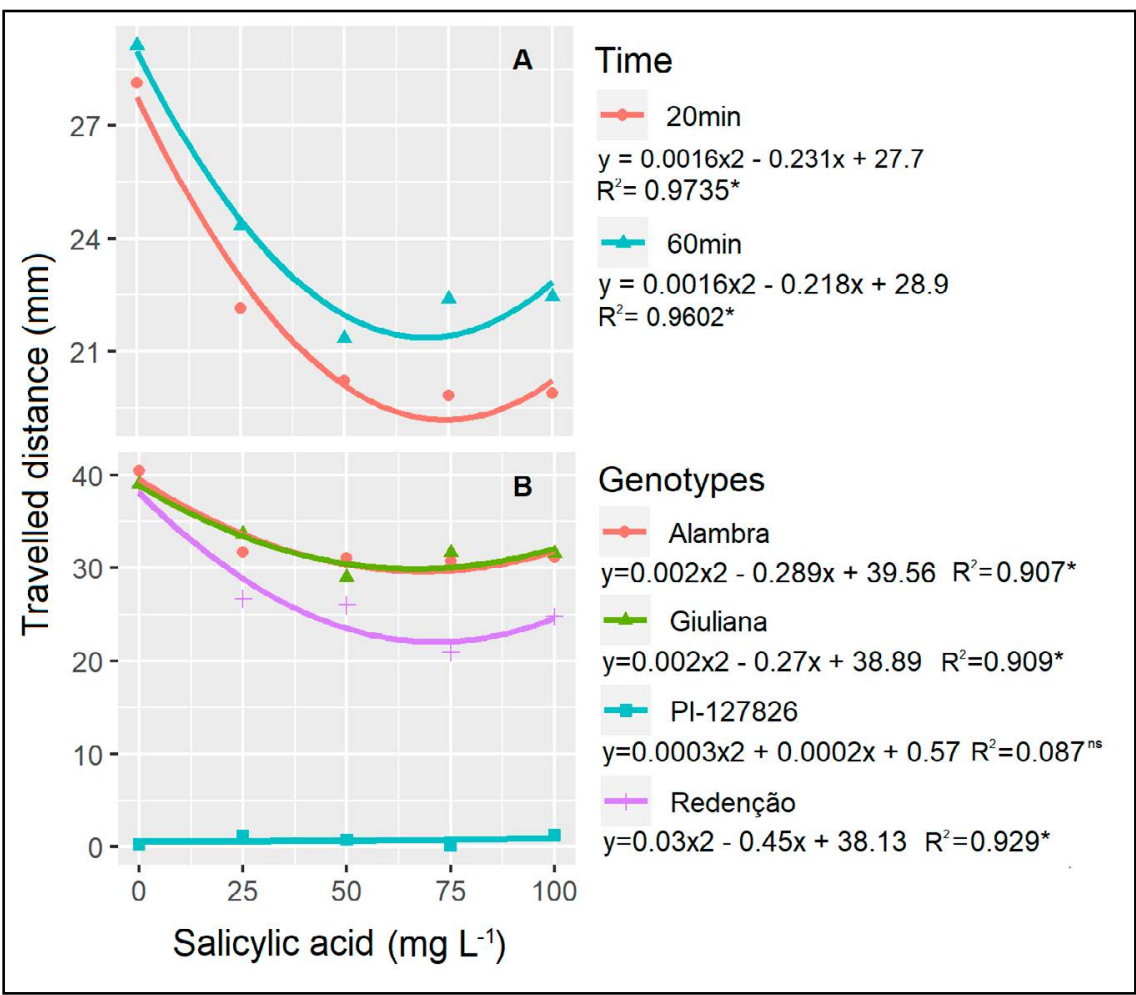

Figure 1. Average travelled distance in $\mathrm{mm}$ (DT) by the two-spotted spider mite (Tetranychus urticae) on tomato leaflets treated with different concentrations of salicylic acid $\left(\mathrm{mg} \mathrm{L}^{-1}\right)$ at 20 and 60 minutes (A) and 40 minutes (B). Guarapuava, UNICENTRO, 2016. jasmonate. On the other hand, Ament et al. (2004) found a specific response of tomato to attack by T. urticae, which seems to induce simultaneously both JA and SA dependent resistance. This may explain the reason why higher SA concentrations were necessary to cause a significant effect on twospotted spider mite management as compared to pinworm. JA and SA, when applied simultaneously, reduced defense induction against herbivores (sucking and chewing) due to a negative crosstalk between some pathways of these hormones (Schweiger et al., 2014). This crosstalk is characterized by an antagonism between the response to SA and JA, the latter being co-activated by ethylene, which inhibits SA-mediated responses (Brodersen et al., 2006).

As expected, the wild genotype ( $S$. habrochaites var. hirsutum accession PI-127826) showed greater resistance to the two-spotted spider mite and tomato pinworm as compared to the commercial genotypes. In addition, the accession PI-127826 was less responsive to the salicylic acid treatments, having a significant influence only on the percentage of consumed leaf area by pinworm, with $10.24 \%$ of leaf area consumed with the application of 67.7 $\mathrm{mg} \mathrm{L}^{-1}$ concentration. The low influence of SA application was perhaps due to the high level of constitutive defense of PI-127826 provided by the presence of allelochemicals produced in glandular trichomes, mainly type IV and VI, which were found in a high quantity in this genotype (Lima et al., 2015; Bergau et al., 2015).

The density of leaf trichomes and, consequently, allelochemical production are possibly dependent on jasmonaterelated immune responses (EscobarBravo et al., 2017). On the other hand, salicylate acts on other tissues promoting responses such as induction of genes related to pathogenesis-related (PR) proteins, which have antimicrobial activity (Van Loon et al., 2006), accumulation of reactive oxygen species (ROS) associated with programmed cell death, and methylation of salicylic acid into methyl salicylate (MeSA) (Van Schie et al., 2007), a volatile compound that induces immune response in nonattacked leaves and neighboring plants 
and attracts natural predators of the arthropod-pest (Aljbory \& Chen, 2017).

In consequence, the insensitivity of PI-127826 genotype to SA found in the present study suggests that the allelochemical production is independent of the SA signaling pathway. On the other hand, the influence of SA application on the percentage of consumed leaf area in PI-127826 suggests that this type of damage may be associated with the acquired systemic resistance (ASR), mediated by salicylate, instead of the constitutive resistance present in the genotype. These results are in agreement with Kawazu et al. (2012) who observed an increase in the expression of SAinduced PR-genes after the beginning of tomato leaf blade consumption by the leafminers Liriomyza sativae, although the expression of SA-related genes was low during oviposition. Those authors pointed out that SA-induced response seems to be more associated with JAmediated suppression than with SA accumulation. This may be associated with plant plasticity in terms of resource allocation (trade-off). Since resources destined to a particular process become unavailable for others, such as on dichotomy between defense and growth, plants can allocate energy to certain pathways over others to ensure effective defenses to specific types of attacks (Vries et al., 2017).

Most genes related to immune responses and defense metabolites production were lost throughout the process of domestication and breeding of crop plants. While the wild tomato has a large number of glandular trichomes, this number is very low in commercial genotypes (Lima et al., 2015; Silva et al., 2019). Thus, cultivated tomato requires other defense strategies against herbivorous attacks, such as hormonemediated defense induction. Thus,

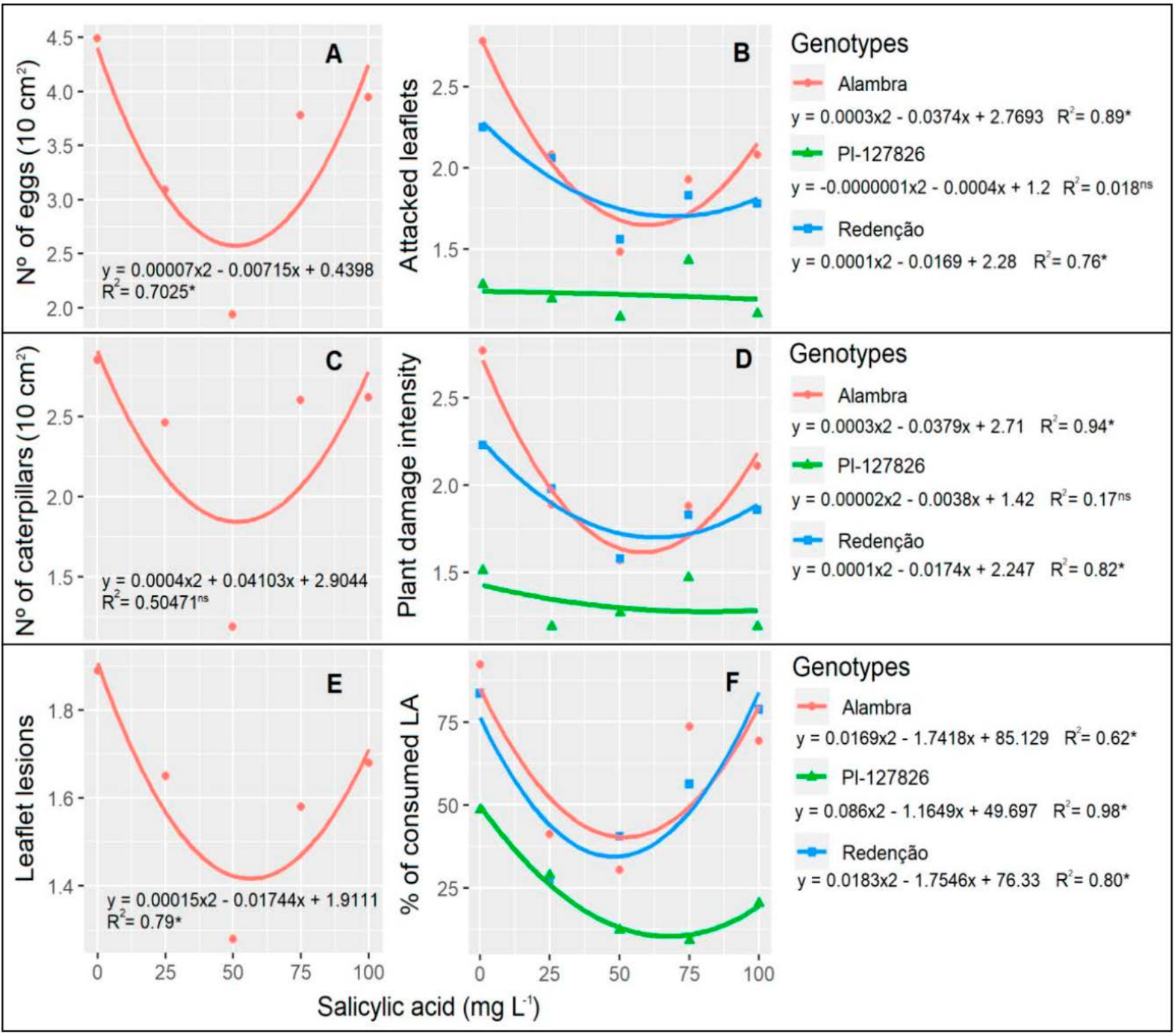

Figure 2. Average number of eggs (NE) $10 \mathrm{~cm}^{-2}$ of leaf area (A), average number of leafminers (NL) $10 \mathrm{~cm}^{-2}$ of leaf area (B), average score scale value for plant damage intensity (PDI) (C), average score scale value for percentage of attacked leaflets (PAL) (D), average score scale value for types of leaflet lesions (TLL) (E) and percentage of consumed leaf area (PCL) (F) by pinworm (Tuta absoluta) in tomato plants treated with various concentrations of salicylic acid. Guarapuava, UNICENTRO, 2016. 
the results obtained in the current study indicate that resistance induction in these plants depends on defense responses mediated by salicylic acid.

Among the analyzed commercial genotypes, 'Redenção' showed a reduction of spider mite travelled distance when compared to 'Alambra' and 'Giuliana' at 60 minutes after exposure (Table 1). Similarly, at 40 minutes, the regression analysis indicated a lower spider mite travelled distance on 'Redenção' at all concentrations, with the shortest travelled distance (21.3 $\mathrm{mm}$ ) estimated at the concentration of $75 \mathrm{mg} \mathrm{L}^{-1}$, while 'Alambra' (28.1 $\mathrm{mm}$ at $\left.72.3 \mathrm{mg} \mathrm{L}^{-1}\right)$ and Giuliana $(29.8 \mathrm{~mm}$ at $67.5 \mathrm{mg} \mathrm{L}^{-1}$ ) showed a similar behavior (Figure 1). At 20 minutes, commercial genotypes did not differ from each other (Table 1).

In the pinworm bioassay, 'Redenção' showed reduction on plant damage (PDI) of $33.1 \%$ at concentration of 87 $\mathrm{mg} \mathrm{L}^{-1}$. For 'Alambra', reduction was $45.3 \%$ on concentration of $63.1 \mathrm{mg} \mathrm{L}^{-1}$ (Figure 2). Concerning severity of the attacked leaflets, cultivar 'Redenção' reduced the leafminer attack intensity by $43.6 \%$, on concentration of $84.5 \mathrm{mg}$ $\mathrm{L}^{-1}$ and 'Alambra', $29.1 \%$ reduced these damages on the concentration of 62.3 $\mathrm{mg} \mathrm{L}^{-1}$, as compared to the respective controls. Overall, Redenção cultivar was less damaged by pinworm attack as compared to Alambra hybrid. However, Alambra tomato was more responsive to salicylic acid, since it showed greater control efficiency at lower doses of the compound.

This may be associated with the mechanism of action of SA since when a plant is attacked, salicylate concentration increases drastically, triggering the degradation of the transcription factor NPR1 (NONEXPRESSER OF PR GENES1), responsible for the induction of resistance genes. NPR1 degradation induces an increase in the level of reactive oxygen species (ROS), especially hydrogen peroxide and superoxide, which induce cell death at the site of injury (Yan \& Dong, 2014). This process is called hypersensitivity response and could explain the increase in plant damage intensity (PDI) observed in 'Alambra'
(Herrera-Vásquez et al., 2015). This performance is in agreement with Peng et al. (2004) who found increases in the levels of endogenous SA, MeSa, and hydrogen peroxide in tomato plants attacked by leafminers of Helicoverpa armigera. In addition, Donovan et al. (2013) found an increase in the levels of SA and ROS in tobacco leaves attacked by aphids (Myzus persicae). In contrast, in cells adjacent to the injury region, SA concentration remained intermediate, which activates the transcription of acquired systemic resistance genes (induced by NPR1). Thus, 'Alambra' may have acquired systemic resistance, which explains the lower number of leaflets attacked (Wu \& Baldwin, 2010) at the maximum dose.

The exogenous application of salicylic acid was effective in reducing the two-spotted spider mite travelled distance and the number of eggs and leafminers, plant damages, and the percentage of leaf area consumed by pinworm in commercial genotypes, thus being an interesting alternative to assist in the integrated pest management on tomato. S. habrochaites var. hirsutum accession PI-127826 had a constitutive defense independent of SA-mediated induction responses, proving more resistant than commercial genotypes.

PI-127826 genotype, considered as a resistant standard, presented the lowest damage severity due to pest attack and the lowest oviposition on the leaflets for both, spider mite and pinworm. Although intermediate doses of salicylic acid were efficient in inducing resistance on evaluated genotypes, they are still less resistant as compared to the wild genotype. It is important to mention that even constitutive resistance can be transferred through crosses between species. It takes a long time to develop commercial materials with good resistance level. In this regard, the results obtained herein indicate the use of salicylic acid as a valuable alternative to pest control in commercial crops, mainly within integrated management program.

\section{REFERENCES}

ALJBORY, Z, CHEN, MS. 2017. Indirect plant defense against insect herbivores: a review. Insect Science 1: 1-22.

AMENT, K; KANT, MR; SABELIS, MW; HARING, MA; SCHUURINK, RC. 2004. Jasmonic acid is a key regulator of spider mite-induced volatile terpenoid and methyl salicylate emission in tomato. Plant Physiology 135: 2025-2037.

BERGAU, N; BENNEWITZ, S; SYROWATKA, F; HAUSE, G; TISSIER, A. 2015. The development of type VI glandular trichomes in the cultivated tomato Solanum lycopersicum and a related wild species $S$. habrochaites. BMC Plant Biology 15: 289-304.

BOSTOCK, RM; PYE, MF; ROUBTSOVA, TV. 2014. Predisposition in plant disease: exploiting the nexus in abiotic and biotic stress perception and response. Annual Review of Phytopathology 52: 517-549.

BRODERSEN, P; PETERSEN, M; NIELSEN, HB; ZHU, S; NEWMAN, MA; SHOKAT, KM; RIETZ, S; PARKER, J; MUNDY, J. 2006. Arabidopsis MAP kinase 4 regulates salicylic acid-and jasmonic acid/ethylenedependent responses via EDS1 and PAD4. The Plant Journal 47: 532-546.

DIAS, DM; RESENDE, JTV; ZEIST, AR; GABRIEL, A; SANTOS, MH; RESENDE, NCV; GUERRA EP. 2019. Resistance of processing tomato genotypes to leafminer (Tuta absoluta). Horticultura Brasileira 37: 40-46.

DONOVAN, MP; NABITY, PD; LUCIA, EH. 2013. Salicylic acid-mediated reductions in yield in Nicotiana attenuate challenged by aphid herbivory. Arthropod-Plant Interactions 7: 45-52.

ESCOBAR-BRAVO, R; KLINKHAMER, PGL; LEISS, KA. 2017. Induction of jasmonic acid-associated defenses by thrips alters host suitability for conspecifics and correlates with increased trichome densities in tomato. Plant and Cell Physiology 58: 622-634.

FAVARO, R.; RESENDE, JTV; GABRIEL, A; ZEIST, AR; CORDEIRO, ECN; FAVARO JUNIOR, JL. 2019. Salicylic acid: resistance inducer to two-spotted spider mite in strawberry crop. Horticultura Brasileira 37 : 60-64.

FERREIRA, DF. 2011. Sisvar: a computer statistical analysis system. Ciência e Agrotecnologia 35: 1039-1042.

HERRERA-VÁSQUEZ, A; SALINAS, P; HOLUIGUE, L. 2015. Salicylic acid and reactive oxygen species interplay in the transcriptional control of defense genes expression. Frontiers in Plant Science 6: 171.

HOWE, GA; JANDER, G. 2008. Plant immunity to insect herbivores. Annual Review of Plant Biology 59: 41-66.

ILIAS, A; VASSILIOU, VA; VONTAS, J; TSAGKARAKOU, A. 2017.Molecular diagnostics for detecting pyrethroid and abamectin resistance mutations in Tetranychus urticae. Pesticide Biochemistry and Physiology 135: 9-14.

KAWAZU, K; MOCHIZUKI, A; SATO, Y; SUGENO, W; MURATA, M; SEO, S; MITSUHARA, I. 2012.Different expression profiles of jasmonic acid and salicylic acid 
inducible genes in the tomato plant against herbivores with various feeding modes. Arthropod-Plant Interactions 6: 221-230.

LABORY, CRG; SANTA-CECÍLIA, LVC; MALUF, WR; CARDOSO, CG; BEARZOTTI, E; SOUZA, JC. 1999. Seleção indireta para teor de 2-tridecanona em tomateiros segregantes e sua relação com a resistência à traça-do-tomateiro. Pesquisa Agropecuária Brasileira 34: 733-740.

LIMA, IP; RESENDE, JTV; OLIVEIRA, JRF; FARIA, MV; RESENDE, MCV; LIMA FILHO, RB. 2015. Indirect selection of industrial tomato genotypes rich in zingiberene and resistant to Tuta absoluta Meyrick. Genetics and Molecular Research 14: 1508115089.

MALUF, WR; INOUE, IF; FERREIRA, RPD; GOMES, LAA; CASTRO, EM; CARDOSO, MG. 2007. Higher glandular trichome density in tomato leaflets and repellence to spider mites. Pesquisa Agropecuária Brasileira 42: 1227-1235.

OJHA, S; CHATTERJEE, NC. 2012. Induction of resistance in tomato plants against Fusarium oxysporum f. Sp. Lycopersici mediated through salicylic acid and Trichoderma harzianum. Journal of Plant Protection Research 52: 220-225.

PENG, J; DENG, X; HUANG, J; JIA, S; MIAO, X; HUANG, Y. 2004. Role of salicylic acid in tomato defense against Cotton Bollworm, Helicoverpa armigera Hubner. Zeitschrift für Naturforschung C 59: 856-862.

SCHWEIGER, R; HEISE, AM; PERSICKE, M, MÜLLER, C. 2014. Interactions between the jasmonic and salicylic acid pathway modulate the plant metabolome and affect herbivores of different feeding types. Plant, Cell and Environment 37: 1574-1585.

SILVA, AA; CARVALHO, RC; ANDRADE, MC; ZEIST, AR; RESENDE, JTV; MALUF, WR. 2019. Glandular trichomes that mediate resistance to green peach aphid in tomato genotypes from the cross between $S$. galapagense and S. lycopersicum. Acta Scientiarum-Agronomy 41: 01-08.

VAN LOON, LC; REP, M; PIETERSE, CMJ. 2006. Significance of inducible defense-related proteins in infected plants. Annual Review of Phytopathology 44: 135-62.

VAN SCHIE, CCN; HARING, MA; SCHUURINK, RC. 2007.Tomato linalool synthase is induced in trichomes by jasmonic acid. Plant Molecular Biology 64: 251-263.

VRIES, J; EVERS, JB; POELMAN, EH. 2017. Dynamic plant-plant-herbivore interactions govern plant growth-defence integration. Trends in Plant Science 22: 329-327.

WESTON, PA; SNYDER, JC. 1990. Thumbtack bioassay: a quick method of measuring plant resistance to twospotted spider mites (Acari: Tetranychidae). Journal of Economic Entomology 83: 501-504.

WU, J; BALDWIN, IT. 2010. New insights into plant responses to the attack from insect herbivores. Annual Review of Genetics 44: 1-24.

YAN, S; DONG, X. 2014. Perception of the plant immune signal salicylic acid. Current Opinion in Plant Biology 20: 64-68.

YOUSSEF, K; OLIVEIRA, AG; TISCHER, CA; HUSSAIN, I; ROBERTO, SR. 2019. Synergistic effect of a novel chitosan/silica nanocomposites-based formulation against gray mold of table grapes and its possible mode of action. International Journal of Biological Macromolecules 141: 247-258.

ZANIN, DS; RESENDE, JTV; ZEIST, AR; OLIVEIRA, JRF; HENSCHEL, JM; LIMA FILHO, RB. 2018. Selection of processing tomato genotypes resistant to two spotted spider mite. Horticultura Brasileira 36: 271-275. 